\title{
The Relationship Between Good Corporate Governance and Performance of Most Liquid Stocks in Indonesia
}

\author{
Abdul Karim ${ }^{1} \&$ Agus Purwanto ${ }^{2}$ \\ ${ }^{1}$ Faculty of Economics and Business, Universitas Semarang, Semarang, Indonesia \\ ${ }^{2}$ Faculty of Economics and Business, Diponegoro University, Semarang, Indonesia \\ Correspondence: Abdul Karim, Faculty of Economics and Business, Universitas Semarang, Semarang, Indonesia.
}

Received: December 19, 2019

Accepted: January 25, 2020

Online Published: March 6, 2020

doi:10.5430/rwe.v11n1p137

URL: https://doi.org/10.5430/rwe.v11n1p137

\begin{abstract}
The purpose of this study is to analyze the influence of independent commissioners, managerial ownership, foreign ownership, debt, and audit quality on the performance of company shares included in LQ 45 on the Indonesia Stock Exchange. The research sample is LQ 45 companies that issued financial statements as much as 120 companies with analysis technique used is multiple regression with one dependent variable and five independent variables. The results showed that foreign ownership, debt and audit quality have significant and positive effects on company performance. Moreover, the insider share ownership and the composition of independent commissioners were proven to not significantly affect company performance. This finding is practically useful to expand the possibility of foreign ownership, facilitate regulation of debt and quality audit obligations to improve stock performance. This study offers a new perspective on the implementation of good corporate governance in the context of the performance of liquid stocks on the stock exchange
\end{abstract}

Keywords: good corporate governance, stock performance, share ownership

\section{Introduction}

There are five pillars in the principles of corporate governance proposed by the OECD, namely fairness, transparency, accountability, responsibility and independence. These pillars underlie the principles of corporate governance according to the OECD, namely the rights of shareholders, fair treatment to shareholders, the role of stakeholders in corporate governance, disclosure and transparency, and the responsibilities of the board of directors (Sulistiyanto and Prapti, 2003; Fujianti, 2018). Corporate governance has one of the most important elements where management ownership is clearly controlled both in private sector and state-owned enterprises (Trihatmoko, 2019). This concerns that trust in corporate governance is related to the amount of share ownership, where high ownership will increase suspicion of conflicts of interest in managing the company. Shleifer and Vishny (1987) found a negative relationship between share ownership by management and corporate governance. This shows that control under these conditions is not free to be carried out effectively because of the involvement of management in operations and supervision simultaneously. In addition, this also shows a negative relationship with company value.

Furthermore, high share ownership is more likely to increase the potential for additional personal portfolios by less diversified management. Potential openness will tend to be more difficult because the possibility of management decisions are not in line with company goals of increasing shareholder-oriented value growth and risk taking. Although several studies have concluded this relationship, the findings generally reveal mixed results regarding the effect of managerial ownership on firm performance. Several studies (e. Himmelberg et al., 1999) found managerial ownership has no significant relationship with company performance. On the other hand, findings by Khanna et al. (2005) states that there is a relationship between ownership and firm value. Benfratello and Sembenelli (2002) and Kozlov et al. (2002) show that foreign companies are known to be more productive than domestic companies. Empirical analysis by Hingorani et al. (1997), Abdullah et al. (2019) find that agency problems are more likely to be reduced by incentives that balance management interests and investor orientation in the case of managerial ownership and foreign ownership. Bushman et al. (2004) in an analysis of debt financing revealed that corporate governance is related to the timeliness of funding. Furthermore, it was also revealed that governance was related to the complexity of the size of the organization, although the findings also found no relationship between the structure of the independent board and managerial ownership. On the other hand, Shapiro (1983), Ferguson et al. (2005), 
Venkataraman et al. (2005) found a positive relationship between audit firm size and audit fee. Hence, the purpose of this study using a study from Karim (2010) as conceptual reference, is to analyze the influence of independent commissioners, managerial ownership, foreign ownership, debt, and audit quality on the performance of company shares included in LQ 45 on the Indonesia Stock Exchange.

\section{Literature Review and Hipotheses}

\subsection{The Relationship Between Independent Commissioners and the Company's Stock Performance}

Fama and Jensen (19830, Pearce and Zahra (1992) found a positive relationship between the number of boards of commissioners and their involvement to increasingly oversee management actions. The composition of the board of commissioners is also related to the role in controlling corporate executives to fulfill aspects of corporate governance. The premise of agency theory is that independent commissioners are needed on the board of commissioners to oversee and control the actions of directors, in connection with their opportunistic behavior (Jensen and Meckling, 1976). Mangel and Singh (1993) argue that independent commissioners have more opportunities to control and deal with a complex web of incentives, which originate directly from their responsibilities as directors and are magnified by their equity positions. Therefore, an independent commissioner is considered as a check and balancing mechanism in increasing the effectiveness of the board of commissioners. In addition, experts who have a similar opinion are Weisbach (1988), Brickley and James (1987) stating that commissioners must be independent and not intimidated by directors / CEOs so as to reduce the consumption of additional managerial income. Pearce and Zahra (1992) also emphasize that the board of commissioners is an effective party in giving a positive influence on management decisions.

\section{H1: The composition of independent directors positively influences the company's stock performance.}

\subsection{The Relationship Between Managerial Ownership and Company Stock Performance}

Agency Theory explains that there is a separation between ownership in a company that will potentially create agency costs due to a conflict of interest between the principal and agent. Eng and Mak (2003) state that when managerial ownership is low, the potential for agency problems will increase. Managers have two choices between increasing incentives to maximize their utility or reducing incentives to improve their performance. Therefore, outside shareholders will try to improve their supervisory function on management behavior in an effort to minimize agency costs that may arise (Jensen and Meckling, 1976). Khana et al. (2005) provide evidence that the relationship between managerial ownership and company performance is clear. Other findings indicate that management ownership is more likely to have a significant influence on firm value (Himmelberg et al., 1999).

\section{H2: Management ownership has a positive effect on the company's stock performance}

\subsection{Relationship of Foreign Ownership With Company Stock Performance}

Foreign ownership in developing countries is thought to be one way to upgrade companies technologically, in developing countries, which can be achieved by direct imports to bring about capital investment and technology adoption (Benfratello and Sembenelli, 2002; Kozlov et al., 2002). Investment in developing countries has the potential for spin-offs (Kozlov et al., 2002). In developing countries, foreign companies along with the amount of capital, resources and technological capacity have more potential to increase competition in the market. This in turn will force domestic companies to take restructuring steps. Some of the restructuring connected to this is to improve the quality of governance, the quality and distribution of goods and the capacity and adoption of technology. This step is necessary because foreign companies, as stated by Kozlov et al. (2002) are more likely to be productive. Some empirical analysis shows that foreign ownership has a positive influence on company performance. In a study in the Czech Republic, Makhija and Spiro (2000) found a positive influence between increasing foreign ownership and stock prices.

\section{H3: Foreign ownership has a positive effect on the company's stock performance \\ 2.4 The Relationship Between Debt and the Company's Stock Performance}

Bushman et al. (2004) in an analysis of debt financing revealed that corporate governance is related to the timeliness of funding. Furthermore, it was also revealed that governance was related to the complexity of the size of the organization, although the findings also found no relationship between the structure of the independent board and managerial ownership. To overcome agency costs from a high level of ownership concentration, managers and insiders can show willingness to be watched by creditors such as banks by increasing their public lending. Harvey et al. (2003) found that in developing markets where there is extreme disproportionate information between insiders 
and outsiders. Companies use debt borrowed in international markets to signal their willingness to be monitored by debt holders.

\section{H4: Debt has a positive effect on the company's stock performance}

\subsection{The Relationship Between Audit Quality and Company Stock Performance}

Previous studies reveal there is more tendency towards independence from large audit firms than management. This is indicated by the proportion of disagreements between the most famous audit companies compared to other audit companies with clients (DeFond dan Jiambalvo, 1993). Some other findings also show that audit quality is related to the use of the most famous audit companies. There are a number of empirical studies that support a positive relationship between audit quality and the size of the audit firm Francis and Simon (1987). Other findings indicate that audit quality reflects corporate governance. Furthermore, Mitton (2002) found a relationship between the use of audit quality and audit opinion generated by the Big Four. Several studies use the use of Big-Four as a proxy for audit quality, and state that there is clarity in relation to transparency and company performance (Furqan et al., 2018).

\section{H5: Audit quality has a positive effect on the company's stock performance}

\section{Research Methods}

The research sample is LQ 45 companies that issued financial statements in 2006 - 2008. Based on the data specifications observed previously, in detail the number of LQ 45 companies listed on the JSX in 2006-2008 and has complete data for cumulative measurement of research variables 120 companies.

Table 1. Details of sample selection

\begin{tabular}{llll}
\hline Sample Selection Criteria & 2006 & 2007 & 2008 \\
\hline $\begin{array}{l}\text { LQ 45 companies listed on the JSX during 2006 - } \\
2008\end{array}$ & 45 & 45 & 45 \\
\hline Banking companies and financial institutions & 4 & 4 & 4 \\
\hline Sample company & 40 & 41 & 39 \\
\hline Total Samples & 120 & & \\
\hline
\end{tabular}

The dependent variable in this study is the company's value which is described by Tobin's Q as a proxy of the company's performance from its share price. The greater the value of Tobin's $Q$ ratio shows that the company has good growth prospects and has greater intangible assets. Tobin's $\mathrm{Q}$ ratio is defined as the market value of equity plus total liabilities and then divided by total assets (Chong and Lopez-de-Silanes, 2006), with the formula:

$$
\begin{gathered}
\text { TOBIN }=(\text { MVE }+ \text { DEBT }) / \text { TA } \\
\text { MVE }=\text { P x Qshares } \\
\text { DEBT }=(\mathrm{CL}-\mathrm{CA})+\mathrm{INV}+\mathrm{LTL}
\end{gathered}
$$

Note: MVE = Market value of outstanding shares; DEBT $=$ Total value of company liabilities; TA=Book value of total company assets; $\mathrm{P}=$ End of year closing stock price; Qshares=Total outstanding shares at the end of the year; $\mathrm{CL}=$ Short-term obligations; $\mathrm{CA}=$ Current Assets; INV= Inventory book value; $\mathrm{LTL}=$ Long-term obligations

The analysis technique used in answering the research problem is to use multiple regression with one dependent variable and five independent variables.

\section{Results}

The company value measured using Tobins $Q$ obtained an average of 1.5488. The average shows that the company is experiencing growth. The average value of the proportion of independent directors as measured by the proportion of the number of independent directors compared to the total number of board of commissioners obtained an average of 0.3671 . The average value of the insider variable was 0.7963 . This means that on average sample companies own $0.7963 \%$ of the company's shares owned by the management, namely the directors and commissioners of the company. The average value of foreign ownership variables was obtained at 23.0475. This means that on average the sample companies own 23.0475 percent of the company's shares owned by foreign companies or individuals. Debt 
ratio that shows the structure of long-term debt to total assets in the sample company shows that the average debt ratio reaches 0.2547 . This means that $25.47 \%$ of the assets used by the sample companies came from the company's long-term debt. Audit quality variables are proxy with auditor qualifications as Big 4 or non-Big 4. Regarding Quality Audit, 54 issuers (49.1\%) were audited by non-Big 4, and 56 issuers (50.9\%) were audited by Big 4 .

Table 2. Descriptive statistics

\begin{tabular}{|c|c|c|c|c|c|}
\hline & $\mathrm{N}$ & Min & Max & Mean & Std. Dev \\
\hline INED & 110 & .0000 & .7500 & .3671 & .1731 \\
\hline INSIDER & 110 & .0000 & 28.7576 & .7963 & 3.4519 \\
\hline FOREIGN & 110 & .0000 & 89.0799 & 23.0475 & 24.1284 \\
\hline DEBT & 110 & .0018 & .6858 & .2547 & .1943 \\
\hline TOBINS Q & 110 & .3347 & 3.6964 & 1.5488 & .7434 \\
\hline
\end{tabular}

Next is hypothesis testing. Testing on first hypothesis showed that the estimation results of the effect of the composition of the independent commissioners on the company's stock performance have the t-value of -1.866 with $\mathrm{p}$-value of $0.065>0.05$. This means that the composition of independent commissioners does not have a significant effect on the value of the company's stock performance. Thus, hypothesis 1 is rejected. The results are consistent with Hermalin and Weisbach (1991), who found evidence that the non executive director (NED) did not influence the company's stock performance.

Table 3. Regression results

\begin{tabular}{|c|c|c|c|c|c|c|c|}
\hline \multirow[t]{2}{*}{ Model } & \multicolumn{2}{|c|}{ Unstd Coeff. } & \multirow{2}{*}{$\frac{\text { Std Coeff. }}{\text { Beta }}$} & \multirow[t]{2}{*}{$\mathrm{t}$} & \multirow[t]{2}{*}{ Sig. } & \multicolumn{2}{|c|}{ Collinearity Statistics } \\
\hline & B & $\begin{array}{l}\text { Std. } \\
\text { Error }\end{array}$ & & & & Tolerance & VIF \\
\hline (Constant) & 1.270 & 209 & & 6.069 & .000 & & \\
\hline INED & -.708 & .308 & -.165 & $\begin{array}{l}-1.86 \\
6\end{array}$ & .065 & .949 & 1.054 \\
\hline INSIDER & -.020 & .019 & -.091 & $\begin{array}{l}-1.02 \\
8\end{array}$ & .307 & .936 & 1.069 \\
\hline FOREIGN & .006 & .003 & 208 & 2.362 & .020 & .960 & 1.042 \\
\hline DEBT & .667 & .335 & .174 & 1.990 & .049 & .966 & 1.035 \\
\hline AUDIT & .465 & .130 & .314 & 3.577 & .001 & .961 & 1.040 \\
\hline $\begin{array}{c}\text { a. } \\
\text { b. } \\
\text { DEBT }+0\end{array}$ & $\begin{array}{l}\text { ndent V } \\
\text { ns Q = } \\
\text { AUDIT }\end{array}$ & $\begin{array}{l}\text { riable: } \\
\text {,270 - }\end{array}$ & $\begin{array}{l}\text { BINS Q } \\
08 \text { INED - }\end{array}$ & 0 INSI & $\mathrm{ER}+$ & 006 FORE & $+0,667$ \\
\hline $\begin{array}{ll}\text { c. } & \text { A } \\
\text { d. } & \text { F }\end{array}$ & $\begin{array}{l}\text { sted R } \\
\text { NOVA) }\end{array}$ & $\begin{array}{l}\text { uare }= \\
6,174\end{array}$ & $\begin{array}{l}2 \\
,=.000\end{array}$ & & & & \\
\hline
\end{tabular}

The results of hypothesis testing of the effect of insider share ownership on company performance show the t-value of -1.028 with $\mathrm{p}$-value of $0.307>0.05$. This means that insider share ownership variable does not have a significant effect on firm value. Thus, hypothesis 2 is rejected. The results are consistent with Khanna et al. (2005), who found evidence that managerial ownership did not affect firm value.

The hypothesis testing of the effect of ownership of foreign shares on the company's performance showed the t-value of 2.362 with $\mathrm{p}$-value of $0.020<0.05$. This means that ownership of foreign shares has a positive and significant effect on firm value. Thus, hypothesis 3 is accepted. The results are consistent Benfratello and Sembenelli (2002), and the research of Kozlov et al. (2002), which shows that foreign companies are known to be more productive than domestic companies. 
The statistical analysis of hypothesis 4 of the effect of debt structure on the company's performance showed the t-value of 1.990 with $p$-value of $0.049<0.05$. This indicates that debt variable has a positive and significant effect on firm value. Thus, hypothesis 4 is accepted. The results are consistent with Harvey et al. (2003) and Bushman et al. (2004) showing that to overcome agency costs from a high level of ownership concentration, managers show a willingness to be monitored by creditors such as foreign corporate banking.

Testing results of the hypothesis of the audit variable on firm value show the t-value of 3.577 with a probability of $0.001<0.05$. This indicates that the audit variable has a positive and significant impact on company performance. Thus, hypothesis 5 is accepted. The results are in line with Francis et al. (2003), who shows that audit is an important element of the stock market, because the audit can increase the credibility of financial information, directly supporting good GCG practices through transparency financial statements. Lastly, the results of data processing show the F-value of 6.174 with a probability of $0.000<0.05$, indicating that the Tobins Q company value can be explained by GCG variables.

\section{Conclusion}

The results of data analysis showed that there was no significant effect between independent commissioners on company performance. The results also reveal that there is a positive but not significant effect between managerial ownership on company performance, which means that the greater the amount of managerial ownership will increase the value of the company. In addition, empirical analysis states that there is a significant positive effect between foreign ownership on company performance, between debt and firm value and between audit quality and firm value. This shows that the audit quality described by the accounting companies included in the Big Four will affect the value of the company. Audit quality usually affects the audit level so that the credibility of the audit results can be relied upon.

The results of this study are theoretically in accordance with previous arguments to improve the quality of corporate governance. In companies with the most traded shares, the drive for governance will be even greater due to its broad influence in the area of capital markets and the economy. These results are practically encouraging publicly listed companies to improve the quality of financial reporting and governance.

This study has several limitations, the main of which is limited to only a few aspects of governance elements that are empirically verified. Other limitations are the limited number of companies analyzed and the cross-sectional study design. Subsequent studies need to examine elements of corporate governance more comprehensively to determine the implementation of governance in public companies, with a number of classified samples. So that implementation elements of governance can be obtained in each type of company, and differences that arise with respect to differences in company capacity and characteristics. In addition, longitudinal analysis is also needed to analyze the relationship of corporate governance with firm value over a longer period of time.

\section{References}

Abdullah, M. I., Furqan, A. C., Parwati, N. M. S., \& Asmanurhidayani. (2019). The effect of public share ownership on tax evasion: Study on companies listed in Indonesia stock exchange between 2008-2011. International Journal of Financial Research, 10(6), 124-132.

Benfratello, L., \& Sembenelli, A. (2002). Foreign ownership and productivity; is the direction of causality so obvious?. Paper presented at the CEPR/LdA Workshop on Labour Market effect of European Foreign Investment.

Brickley, J. A., \& James, C. M. (1987). The takeover market, corporate board composition, and ownership structure: The case of banking. The Journal of Law and Economics, 30(1), 161-180.

Bushman, R., Chen, Q., Engel, E., \& Smith, A. (2004). Financial accounting information, organizational complexity and corporate governance systems. Journal of Accounting and Economics, 37(2), 167-201.

Chong, A., \& Lopez-De-Silanes, F. (2006). Corporate governance and firm value in México. Inter-American Development Bank. Working paper 564.

Defond, M. L., \& Jiambalvo, J. (1993). Factors related to auditor-client disagreements over income-increasing accounting methods. Contemporary Accounting Research, 9(2), 415-431.

Eng, L. L., \& Mak, Y. T. (2003). Corporate governance and voluntary disclosure. Journal of Accounting and Public Policy, 22(4), 325-345. 
Fama, E. F., \& Jensen, M. C. (1983). Separation of ownership and control. The Journal of Law and Economics, 26(2), 301-325.

Ferguson, A., Lennox, C., \& Taylor, S. (2005). Audit fee rigidities in the presence of market frictions: evidence and explanations (1-50). Working paper, University of New South Wales.

Francis, J. R., \& Simon, D. T. (1987). A test of audit pricing in the small-client segment of the US audit market. Accounting Review, 145-157.

Francis, J. R., Khurana, I. K., \& Pereira, R. (2003). The role of accounting and auditing in corporate governance and the development of financial markets around the world. Asia-Pacific Journal of Accounting \& Economics, 10(1), $1-30$.

Fujianti, L. (2018). Top management characteristics and company performance: an empirical analysis on public companies listed in the Indonesian Stock Exchange. European Research Studies Journal, 21(2), 62-76.

Furqan, A. C., Abdullah, M. I., Iqbal, M., \& Masdar, R. (2018). The role of corporate governance on the effect of state ownership on audit findings at state-owned enterprises. European Research Studies Journal 21(3), 218-229.

Harvey, C. R., Liechty, J. C., Liechty, M. W., \& Müller, P. (2003). Portfolio Selection with Higher Moments, Philadelphia. Drexel University.

Hermalin, B. E., \& Weisbach, M. S. (1991). The effects of board composition and direct incentives on firm performance. Financial Management, 101-112.

Himmelberg, C. P., Hubbard, R. G., \& Palia, D. (1999). Understanding the determinants of managerial ownership and the link between ownership and performance. Journal of Financial Economics, 53(3), 353-384.

Hingorani, A., Lehn, K., \& Makhija, A.K. (1997). Investor behavior in mass privatization: The case of the Czech voucher scheme. Journal of Financial Economics, 44(3), 349-396.

Karim, A. (2010). Pengaruh Good Corporate Governance Terhadap Kinerja Saham Perusahaan (Studi Empiris pada Saham LQ 45 di BEI). Maksimum, 1(1).

Khanna, A., Mahenthiran, S., \& Curci, R. (2005). Managerial ownership and firm value: Agency problems of empire building and overvalued equity. Butler University Working Paper, May, Butler University, Indianapolis.

Kozlov, Y. K., Melentieva, N., \& Ponomareva, N. (2002). Does foreign ownership matter?. Working paper. Retrieved from www.ssrn.com/paper. taf

Makhija, A. K., \& Spiro, M. (2000). Ownership structure as a determinant of firm value: Evidence from newly privatized Czech firms. Financial Review, 35(3), 1-32.

Mangel, R., \& Singh, H. (1993). Ownership structure, board relationships and CEO compensation in large US corporations. Accounting and Business Research, 23(sup1), 339-350.

Mitton, T. (2002). A cross-firm analysis of the impact of corporate governance on the East Asian financial crisis. Journal of Financial Economics, 64(2), 215-241.

Pearce, J. A., \& Zahra, S. A. (1992). Board composition from a strategic contingency perspective. Journal of Management Studies, 29(4), 411-438.

Shapiro, C. (1983). Premiums for high quality products as returns to reputations. The Quarterly Journal of Economics, 98(4), 659-679.

Shleifer, A., \& Vishny, R. W. (1997). A survey of corporate governance. The Journal of Finance, 52(2), 737-783.

Sulistyanto, H. S., \& Prapti, M. S. (2003). Good Corporate Governance: Can Enhance Community Trust. Journal of Economics and Business, 4(1), 83-93.

Trihatmoko, R. A. (2019). State-owned enterprises and economic constitutions: a case study of judicial review of law no. 19 of 2003. Jurnal Hukum dan Peradilan, 8(1), 149-165.

Venkataraman, R., Weber, J., \& Willenborg, M. (2005). Litigation risk, audit fees and audit quality: Initial Public Offerings as a natural experiment. Journal of Accounting Research, 43(1), 1-42.

Weisbach, M. S. (1988). Outside directors and CEO turnover. Journal of Financial Economics, 20, 431-460.

Wright, D. W. (1996). Evidence on the relation between corporate governance characteristics and the quality of financial reporting (No. 9601). University of Michigan. 